\title{
Efter Georgien
}

Fjodor Lukjanov

\section{Den nye verdensorden, som alle håbede på for 20 år siden, er stadigvæk ikke blevet til virkelighed.} Men opløsningen af den gamle fortsætter med stadig stigende hast. Måske aldrig nogensinde før har der bestået en så udtalt konflikt mellem Ruslands og Vestens opfattelser som nu

I august 1990 bragte magasinet $A t$ lantic Monthly en artikel af den amerikanske politolog John Mearsheimer, hvis overskrift var: Hvorfor vi snart vil savne Den Kolde Krig.

Som repræsentant for den neorealistiske skole hæudede han i modsætning til så mange andre kommentatorer efter Berlinmurens fald, at den kommende epoke i Europa, og tilsyneladende også i hele verden, ikke ville blive mere, men mindre stabil end Den Kolde Krigs. Hans vurdering byggede på den klassiske realistiske grundopfattelse, at kun magtligevægt kan garantere et politisk bæredygtigt politisk system.

Mearsheimers dystre realisme forekom dengang absolut upassende og forældet. Europa var overvældet af en romantisk tro på, at historien var slut efter den ideologiske hoved- fjendes nederlag, og en ny type politik var hurtigt ved at tage form.

Et af de mest oplagte og mest løfterige symboler på denne politik var Den Europæiske Union, som stilede imod både kvalitativ integration $\mathrm{i}$ dybden og en omfattende geografisk udvidelse. I mellemtiden erklærede også Rusland sin vilje til at slutte sig til det vestlige fællesskab.

Når vi dag står over for en verdensomspændende politisk usikkerhed, som forværres af de finansielle tumulter, er der grund til at spørge: Hvad gik galt? Hvorfor gik forventningerne fra de sene 1980 'ere og de tidlige 1990'ere ikke i opfyldelse? Hvorfor forekommer Mearsheimers logik pludselig mere relevant til belysning af den aktuelle situation end de liberale fortolkninger? Og hvorfor viste så mange ideer om den nye 
verden sig at være ønsketænkning fra første færd?

\section{Vendepunkterne}

Vi har gennemlevet mange omvæltninger i de seneste to årtier, og flere kan betegnes som historiske. Men efter min mening er der navnlig to begivenheder, som med rette kan gøre krav på at være vendepunkter. Disse er Sovjetunionens sammenbrud i 1991 og USA's invasion af Irak i 2003. Begge kom definitivt til at ændre verdenssituationen og følgelig også Ruslands adfærd. Den Globale Finanskrise 2008 kan blive den tredje skelsættende hændelse, der fuldender en 20-årig post-koldkrigsæra.

Med Sovjetunionens kollaps i december 1991 forsvandt det vældige eurasiske imperium, som i århundreder havde udgjort en sjettedel af klodens landoverflade, og som i 50 år var en af de to piller, der bar verdensordenen. I stedet trådte en helt ny virkelighed. For første gang i historien var USA verdens leder og kunne tilrane sig ansvaret for hele verden, mens Rusland havde lidt et alvorligt geopolitisk nederlag og måtte kæmpe for sit liv som en suveræn stat.

Diskussionerne om, hvorvidt der dengang bød sig en reel chance for at integrere Rusland snævert i det vestlige system vil formentlig aldrig høre op, men hvis der var en sådan chance, så blev den ikke grebet.
En af grundene til dette var, at opgavens enorme omfang blev undervurderet. Den udbredte opfattelse var: Liberale økonomiske reformer vil før eller siden forandre den russiske stats karakter på samme måde, som det var sket i Central- og Østeuropa. Denne anskuelsesmåde tog ikke højde for ikke-økonomiske faktorer. I modsætning til de andre postkommunistiske lande var Ruslands tilvante rolle at være en stormagt med stærke, imperiale geopolitiske traditioner og erfaringer inden for verdensdominans. Aldrig før var sådanne magter blevet radikalt forandret uden at være besejret militært.

Clinton-regeringen gjorde ganske vist Ruslands forvandling til et af sine højt profilerede projekter. Der kom imidlertid ikke banebrydende nye ideer som Marshall-planen eller Europas forening på grundlag af et samarbejde mellem de tidligere svorne fjender, Frankrig og Tyskland. Samtidig krævede den russiske særegenhed og betydning for verdensordenen noget langt mere innovativt end det universelle reformistiske mønster i små og mellemstore lande.

De vestlige bestræbelser fokuserede på at udbrede de vestlige institutioner, som havde vist deres effektivitet i årene med ideologisk konfrontation, snarere end at skabe nye strukturer for en ny verdensorden. Den generelle opfattelse forekom at være: Hvorfor skabe noget nyt, når man kan tilpasse velafprøvede og velfungerende organisationer? 
Mere end ti år senere står to ting klart. For det første, at Vestens fredelige ekspansion kun var mulig, fordi tiden var unik. Rusland var i geopolitisk koma og ude af stand til at gøre modstand. Kina var optaget af sin egen udvikling og tænkte endnu ikke på at påtage sig nogen global rolle. De lande, som pludselig havde vundet handlefrihed, dannede en lang $\mathrm{k} \emptyset$ for at slutte sig til alle mulige vestlige organisationer.

Men så snart Vesten mistede sit monopol på indflydelse på verdenspolitikken, vågnede Rusland, Kina blev en magtfuld kraft, og den udvikling, som blev taget for givet $\mathrm{i}$ 1990'erne, kom i akut krise.

For det andet blev det indlysende, at de gamle institutioner var ude af stand til at klare de nye udfordringer. Ikke en af de strukturer, som man antog ville blive instrumenter for global regeringsførelse, har kunnet varetage denne funktion, og dette bør ikke komme som nogen overraskelse. Disse er, når alt kommer til alt, produkter af en tidligere epoke, hvor alting var ganske anderledes. Nogle organisationer er ikke blot ikke i stand til at forstærke stabiliteten, men svækker den ligefrem: Fra at være et redskab til at eksportere sikkerhed, er NATO blevet en katalysator for alvorlige konflikter.

\section{Forældede institutioner}

Da Mearsheimer skrev sin artikel i 1990, kunne han for øvrigt end ikke forestille sig, at NATO ville overleve Den Kolde Krigs slutning.

For det første forekom det utænkeligt, at Sovjetunionen/Rusland ville acceptere eksistensen af et NATO efter Warszawa-pagtens opløsning, og for det andet var det svært at tro, at alliancen selv ville være i stand til at opretholde sin enhed efter bortfaldet af dens væsentligste trussel. Hvad det første angår, undervurderede han Mikhail Gorbatjovs romantiske forestillinger. Hvad det andet angår, forekommer hans skepsis i dag ret velbegrundet.

Så langt tilbage som i 1990'erne begyndte de internationale institutioner, som ikke var reformeret efter Den Kolde Krigs afslutning, at vise tegn på dysfunktion. Frem for at påtage sig processen med at transformere det internationale system besluttede verdens ledende magt på dette tidspunkt sig i stedet til at gå sine egne veje og forlade sig på egen styrke og muligheder. USA havde, når alt kommer til alt, også rigeligt af begge dele. Irak-invasionen i foråret 2003 blev kulminationen på denne tilgang. Militær styrke, hvis betydning i 1990'erne så ud til at mindskes væsentligt, er nu vendt tilbage i verdenspolitikken i fuld skala og i sin mest brutale form.

Da det viste sig, at supermagten, som var trådt i stedet for alle de internationale regeringssystemer, havde strakt sig til det yderste og i realiteten var ude af stand til at opfylde de funktioner, den havde påtaget 
sig, blev den globale udviklings kaotiske natur afsløret. Hvis Irak-invasionen var en overlagt handling fra USA's side, som havde som mål at realisere denne eller hin plan, så var den anden flagrante krænkelse af international ret - anerkendelsen af Kosovo - et resultat af afmagt. Washington og de europæiske hovedstæder kom til den konklusion, at det var lettere at føje sig for kosovarernes krav end at lægge et smerteligt stort arbejde $\mathrm{i}$ at forsøge at nå et udfald, som kunne være acceptabelt for alle.

Når man skal indrette sig på vilkår, hvis kendetegn er generelt kaos og dysfunktionelle institutioner, er den rationelle handlemåde at øge sin egen styrke, så man sætter sig selv i stand til at reagere på udfordringer, der kan opstå uden varsel. Dette er, hvad Rusland har gjort i de seneste fem år i en periode, der har været præget af prisstigninger på olie og naturgas uden fortilfælde.

Det ofte stillede spørgsmål er følgende: Hvad er Ruslands strategi? Der findes ikke noget svar på dette. De russiske handlinger, eller i det mindste de handlinger, som fremkalder den stærkeste reaktion, er som regel en mere eller mindre spontan reaktion på eksterne pirringer. En blanding af post-imperial nostalgi, frygt for talrige udefrakommende udfordringer, et lidenskabeligt ønske om at 'genopføre' den sidste fase af Den Kolde Krig, da Sovjetunionen (ifølge en fortolk- ning, som har vid udbredelse i dagens Rusland) ikke blev besejret, men frivilligt lod sig omringe, samt irritation over vestens triumferende hovmod efter 'historiens slutning' har stærk indflydelse på russisk udenrigspolitik og gør den mindre fornuftsbetonet.

Vi kan stille et andet spørgsmål: Har nogen af de større internationale spillere en velovervejet og langsigtet strategi? Og er dette overhovedet muligt i vore dages verden?

Hvordan skal man opfatte den amerikanske regerings politikker som en gennemtænkt strategi, hvis resultaterne er de modsatte af de tilsigtede, og fremtidsudsigterne tegner uklare?

Hvad er strategien for EU, der nu er gidsel for sin egen idé om fremgang og indflydelse og er viklet ind i den uløselige modsætning mellem ekspansion og tættere integration? EU-modellen blev under alle omstændigheder udviklet i helt andre omgivelser: Oprindelig tog den form under en amerikansk sikkerhedsparaply og dengang på vilkår, der var defineret ved et snævert geopolitisk ‘ånderum'. EU, som for 1015 år siden forekom at være prototype for de fremtidige principper for verdenspolitik, ligner nu en undtagelse i en generel verdensuorden. Den internationale udvikling har overhalet den smukke 'morgendag' og er rykket direkte frem til 'dagen efter morgendagen', som i ubehagelig grad ligner 'i går'. 
Kina giver indtryk af en planlagt bevægelse imod et mål, som er besluttet for nogen tid siden. Det er imidlertid vanskeligt for øjeblikket at nå frem til konklusioner om de eksterne mål for Beijing - Kina er stadig optaget af sin egen indre udvikling.

Globaliseringen er blevet diskuteret længe og såre grundigt, men når det gælder den større politiske scene, fortsætter alle af en eller anden grund med at betragte de forskellige elementer på verdens palet som adskilte. Men i den nuværende situation er det umuligt at opridse strategien for hver individuel spiller: Vi må første have en idé om de strategiske udsigter for verdens udvikling. Dette kan kun ske som resultat af et fælles forsøg på først at forstå situationen og derpå formulere bud på løsninger på problemerne.

Det er almindeligt anerkendt, at ingen har nogen klar forståelse af, hvad der foregår på finansmarkederne, som har revet sig fri fra enhver rationel, forståelig realitet. Men situationen på storpolitikkens 'markedsplads' er ikke meget bedre. Så meget desto mere magtfuld er tiltrækningen ved mønstre, vi forstår, som da også ligger til grund for det brændende ønske om at rekonstruere noget i retning af Den Kolde Krig. Det vil der imidlertid ikke komme noget ud af, og jo mere ihærdigt forsøget gøres, desto mere destruktivt vil udfaldet blive.

Verdensordenens stabile systemer finder traditionelt deres form efter store krige. Den Kolde Krig var unik i den forstand, at den blev afsluttet uden væbnet konflikt. Men den nye verdensorden, som alle håbede på for 20 år siden, er stadigvæk ikke blevet til virkelighed, mens opløsningen af den gamle fortsætter med stadig stigende hast. Alle store lande står over for en enorm intellektuel udfordring - hvordan forhindre opløsningen $\mathrm{i}$ at nå sin logiske konklusion, hvilket vil indebære enorme konflikter? Og hvordan begynde at konstruere et system, som tager hensyn til interesserne hos alle de involverede lande?

\section{Rystelser i Rusland}

Og her kommer vi til den tredje historiske begivenhed, som vi alle står overfor lige nu. Rusland er igen hårdt ramt af denne.

To kriser er indtrådt i de seneste måneder og har, den ene efter den anden, fået enorm indvirkning på Ruslands udenrigspolitik. Den russisk-georgiske krig i august og rystelserne på de globale finansmarkeder i september og oktober er ikke forbundne størrelser. Alligevel har begge begivenheder på hver sin måde bidraget til, at Rusland har reformuleret sine nationale interesser. Man kan sige, at de to kriser har sat den begrebslige ramme for dets interesser, defineret en vektor for det ubetinget nødvendige og sat grænser for det mulige. 
Georgiens angreb på Sydossetien og verdens reaktion på Ruslands modtræk har skabt en ny situation i russisk politik og i den offentlige opinion. Måske aldrig nogensinde før er der bestået en så stor konflikt mellem Ruslands og Vestens opfattelser som nu. Ruslands politiske elite og langt den overvældende majoritet af befolkningen er i et meget sjældent tilfælde af enstemmighed af den opfattelse, at Ruslands handlinger var legitime, politisk, moralsk og juridisk. Ydermere havde Kreml ganske enkelt intet valg, og Moskva havde ingen ret til ikke at gribe ind for at forsvare Sydossetiens befolkning og dets egne fredsbevarende soldater.

Dette synspunkt er næsten enstemmigt og ganske oprigtigt. Dette er grunden til, at reaktionen fra de vestlige lande, især De Forenede Stater, som tog parti for Tbilisi, har afstedkommet forvirring i Rusland. Man må indrømme, at siden da er den vestlige holdning til Georgien blevet mere nuanceret, men det oprindelige instinkt fungerede upåklageligt - Vesten troede virkelig på, at russiske revanchister gik til angreb på et 'ungt demokrati'.

Uden at gå ind i enkelthederne om, hvad der skete, vil jeg gerne fremhæve den væsentligste faktor, som jeg tror, vil få følger på langt sigt. Måske for første gang siden Sovjetunionens sammenbrud måtte Moskva konstatere, at det var nødt til at handle uden hensyn til de mu- lige omkostninger ved verdens reaktion. Konflikter havde tidligere fundet sted, men som regel var beslutningerne så blevet truffet, afhængigt af hvordan de kunne påvirke relationerne til 'strategiske partnere'. Behovet for at opretholde gode relationer til de ledende vestlige lande, som blev anset for et aksiom, havde sat betydelige grænser for Rusland reaktioner og på dets fortolkning af sine nationale interesser.

Denne gang konkluderede Kreml, at de handlinger, som ydre partnere kunne bifalde, ville koste for meget set ud fra landets egne vitale interesser. Ydermere var det overvejende sandsynligt, at det ville være umuligt at fastholde disse interesser uden at komme i konflikt med store internationale partnere. Hertil kommer, at det ikke nyttede at håbe på, at disse partnere ville forstå Ruslands interesser eller bare logikken i den russiske adfærd.

Sidstnævnte overvejelse førte sandt at sige Moskva til at træffe den mest kontroversielle beslutning under krisen - nemlig at anerkende Abkhasien og Sydossetien. Det var ikke den oprindelige plan, og at dømme efter dets udtalelser, var Moskva ikke forberedt på at gennemføre 'Kosovo'-modellen i løsrivelsesterritorierne - dvs. en international diskussion af deres status, som før eller siden ville udmunde i den konklusion, at de ikke længere kunne forblive under Tbilisis overhøjhed.

Imidlertid fik Vestens reaktion på 
Femdages-krigen og åbenlyse modvilje mod at acceptere det russiske syn på begivenhederne, Rusland til at tænke, at et kompromis var umuligt, og at De Forenede Stater og hovedparten af de europæiske lande kun ville tage hensyn til interesserne for den stat, som de troede var 'ofret', nemlig Georgien.

Som et resultat heraf kom Rusland ud af Georgien-krigen med en beredvillighed til at forsvare sine vitale interesser, uanset de ydre partneres reaktion og uanset hvor megen støtte Rusland kunne forvente fra disse i fremtiden. Dette er en afgørende fase i landets udvikling. Samtidig tid må der være klare kriterier for at vurdere, hvilke interesser, der er vitale og skal opretholdes, uanset omkostningerne. Rusland er et land, der stadig befinder sig i en overgangsfase, og det har ikke sådanne klare kriterier endnu, skønt deres definitioner er ved at udmønte sig. Den anden krise, finanskrisen, har spillet en væsentlig rolle i så henseende.

\section{Finanskrisen}

Den finansielle ustabilitet, som hurtigt har spredt sig verden over, har afsløret en grad af gensidig global afhængighed og vist, at der er grænser for økonomiske og følgelig også for geopolitiske kapaciteter. Det har $\mathrm{fx}$ vist sig, at de enorme finansielle ressourcer, som er akkumuleret igennem år med vedvarende økono- misk vækst, kan være nok til at afbøde konsekvenserne af den nationale krise. Alligevel er de ikke tilstrækkelige til at gennemføre nogen af de større geopolitiske projekter, som er planlagt i de senere år.

Krisens realitet vil få landene til at foretage klarere prioriteringer, rangordne deres hensigter og tilsidesætte sekundære opgaver til fordel for de vigtige. Disse stringente vilkår vil hjælpe Rusland til at udarbejde kriterier til at identificere sine vitale interesser. Dette vil, tror jeg, blive uundgåeligt allerede i nær fremtid.

Samtidig er der også en positiv side ved finanskrisen: Verden har nu genoptaget diskussionerne om behovet for tidssvarende globale regeringsinstitutioner. Rusland har talt om forfaldet i de eksisterende institutioner i lang tid, men ingen har lyttet til dets advarsler. Fx opfordrede Rusland for halvandet år siden til reform af Den Internationale Valutafond og foreslog en alternativ kandidat til posten som direktør for IMF. Imidlertid besluttede Vesten, at Moskvas udspil alene var 'et udslag af chikane', der skulle manifestere dets store betydning på den internationale arena. I dag er det fuldkommen indlysende, at hverken IMF eller dets siddende direktør er i stand til at varetage deres opgaver behørigt.

En anden russisk tanke er en bred international dialog om euro-atlantisk sikkerhed, som i Vesten er blevet mødt uden større begejstring - af objektive og subjektive grunde. $\mathrm{Og}$ 
dog er denne tanke ganske fornuftig. Alle institutioner, der håndterer sikkerhedsspørgsmål, har deres rødder i Den Kolde Krigs epoke, dvs. blev indrettet efter en helt anden virkelighed.

Da Den Kolde Krig var ovre, valgte Vesten ikke at etablere nye institutioner, som kunne tjene en 'ny verdensorden'. Det søgte i stedet at udbrede indflydelsen fra de institutioner, som havde 'vundet' Den Kolde Krig, dvs. fra de vestlige institutioner. Nu ser vi resultaterne - de er ude af stand til at håndtere den nødvendige regulering i den nye virkelighed, om det så gælder globale politiske beslutninger, sikkerhedssfæren eller økonomien.

Den finansielle krise kan få alle lande, Rusland indbefattet, til at besinde sig på deres kollektive interesser og behov for multilaterale handlinger og give afkald på de selviske interesser, som alle globale spillere nu har, uden undtagelse. I modsat fald vil verden opleve et yderligere forværret kaos og en voksende rivaliseren, som - på den gensidige afhængigheds vilkår - kan få særdeles farlige konsekvenser.

\section{Helsinki 2}

Udviklingen i de seneste måneder har vist, at europæisk politik er et komplekst fænomen. Man kan ikke adskille $ø$ konomisk samarbejde fra sikkerhedsspørgsmål. Det er grunden til, at tanken om Helsinki 2, som Moskva har søgt at fremme, er det rette initiativ til tiden. Europa behøver en grundlæggende aftale om principielle rammer, der ligesom Slutdokumentet af 1975 kan omfatte forskellige kategorier. Fra militære garantier for grænser (som igen er meget akut) til økonomi, fra energi til humanitære retningslinjer.

Et kendetegn ved den aktuelle internationale situation er den åbenlyse fremvækst af meget forskellige former for rivalisering, kombineret med en stigende gensidig økonomisk afhængighed mellem disse rivaler. Dette forvandler de yndede sammenligninger med det 19. århundredes 'Store Spil', forspillet til Første Verdenskrig eller Den Kolde Krigs periode, til rent nonsens.

Finanskrisen giver os mulighed for at komme tilbage til den reelle agenda for en ny international arkitektur, som af forskellige grunde blev opgivet efter Den Kolde Krig. Både Rusland og Vesten forspildte talrige chancer for at skabe nye rammer for deres relationer. Trods de åbenlyse vanskeligheder i dagens verden har vi fået en ny chance, lige netop nu.

Den georgisk-russiske krig og de efterfølgende begivenheder har mindet os om, at selv nu, næsten to årtier efter at Sovjetunionen forsvandt fra verdenskortet, er dets territorium stadig eksplosivt. Opbruddet er ikke tilendebragt endnu.

Sammenbruddet for det imperium, som i århundrede havde struk- 
tureret det vældige eurasiske rum, satte gang i tektoniske forskydninger. Det er vanskeligt at sige, hvornår disse vil ophøre og hvad de vil resultere i. Hvis, fx transformationen af det postsovjetiske rum resulterer i opkomsten af et islamistisk regime i en centralasiatisk stat, vil Sovjetunionens sammenbrud blive set $i$ et helt andet lys. Alle de stater, der er vokset frem i Sovjetunionens sted (Den Russiske Føderation indbefattet), hviler på en skrøbelig og ustabil statsdannelse.

For det første eksisterede ingen af dem tidligere inden for deres nuværende grænser, ja i mange tilfælde kan disse grænser ikke betegnes som 'naturlige' - hverken i historisk, etnisk eller psykologisk forstand.

Hvorfor er fx territorier med overvejende ikke-russisk befolkning (Nordkaukasus) eller territorier, som Rusland har erhvervet sig for relativt nylig (Kaliningrad), en del af Rusland, hvorimod Kiev, den russiske stats vugge, ikke er det? Der findes ingen rationel begrundelse for den slags - det er historiens luner.

Der er et grænseløst potentiale for territoriale konflikter - og ikke alle involverer Rusland. Et eksempel: Da Vladimir Putin på NATO-topmødet i Bukarest forklarede George Bush, at Ukraine er en 'kunstig stat' (hvorved han sigtede til udvidelsen af dets territorium i Sovjettiden), rankede Rumæniens præsident, Traian Bse$\mathrm{cu}$, ryggen. Nogle dage senere stod han offentligt frem og erklærede, at
Ukraine havde opnået Sydbessarabien og Nordbukovina takket være Molotov-Ribbentrop-pagten. Det er ikke vanskeligt at forestille sig ophidsede territoriale stridigheder $\mathrm{i}$ også Centralasien, hvor kontrol over vandressourcer har vital betydning for overlevelse.

For det andet har ingen af de postsovjetiske lande skabt sig nogen national identitet. Med en mulig undtagelse af det monoetniske Armenien er befolkningen i de tidligere sovjetrepublikker multinational. Ingen har fået succes med at opbygge en moderne civil nation, der ikke er baseret på blodets faktor, men på tilhørsforholdet til en fælles stat. Tværtimod er statsdannelsen overalt sket langs etniske linjer. (Hviderusland er eneste undtagelse her - og dog er den nationalistiske genfødsel her snarere udskudt end forhindret.) Den internationale kontekst bidrager også til denne problematik. I Kosovos tilfælde foretrak det internationale samfund med forsæt at se en stat fragmentere efter etniske linjer i stedet for at gøre forsøge på at bevare en multikulturel entitet.

Jo hårdere et styre søger at etablere et sprog eller en bestemt version af landets historie som den dominerende, og jo større betydning de tilskriver titulærnationen, desto større er potentialet for sociale spændinger.

Fortiden bliver et instrument for selv-identifikation, som antager et nationalistisk anstrøg. Fx har det officielle krav fra Kiev om at hungers- 
nøden først i 1930'erne skal anerkendes som et folkemord imod det ukrainske folk, en oplagt, om ikke erklæret politisk implikation - nemlig, at ukrainerne blev myrdet på ordre fra Moskva.

Besættelsesmuseerne i Tbilisi og Kiev, Koloniseringsmuseet i Tasjkent og diverse appeller om at sidestille kommunismen med nazismen bliver brugt til at legitimere bestemte politiske aspirationer. Den historiske polemik bliver stadig mere ophidset, og det samme gør spændingerne landene imellem og mellem den tidligere periferi og moderlandet især når Rusland selv afviser at tage sin fortid op til revision og tillige forsøger at opbygge sin identitet på elementer af historisk nationalistisk farvede myter.

$\mathrm{Og}$ for det tredje har ingen af de postsovjetiske lande noget veletableret sociopolitisk system. Et politisk regimes demokratiske niveau bør ikke blot måles ud fra dets institutioners tilstand, men også ud fra dets geopolitiske orientering. Georgiens eksempel viser åbenlyst, at en aktiv proamerikansk position har større vægt end ægte hengivenhed over for demokratiske principper.

Generelt sagt skader sammenfletningen af eksterne geopolitisk strategier med de postsovjetiske staters indre udvikling denne proces. Bliver demokratiet gjort til et instrument, bliver selve demokrati-begrebet bragt i miskredit og forhindrer den naturlige modning, som er normal forhåndsbetingelse for en demokratisk udvikling.

I en situation, hvor overgangslandes tilhørsforhold til 'Klubben' er givet på forhånd, som tilfældet var med de central- og østeuropæiske stater, kan eksternt formynderskab fremme reformer. Men hvis et land bliver genstand for global rivaliseren, kan transformationen blive alvorligt kompliceret. Intervention udefra kan influere på processer i landene på forskellige måder - som en katalysator for regimeskift og som et incitament til aggressiv bevarelse af det bestående og forkastelse af forandringer. I begge tilfælde kan resultatet blive sørgeligt for moderniseringen.

De postsovjetiske lande behøver 15-20 års fredelig udvikling for endelig at etablere sig selv som suveræne og stabile stater. Forsøg på at eskalere processen med geopolitisk nyopdeling af den sovjetiske arv ved at involvere lande i forskellige geopolitiske alliancer kan skabe alvorlige rystelser.

Fjodor Lukjanov er chefredaktør for magasinet Rossija v globalnoj politike (Rusland $i$ verdenspolitikken); en russisk pendant til det amerikanske tidsskrift Foreign Affairs og til vores eget Udenrigs. Magasinet har også en engelsk hjemmeside: http://eng.globalaffairs.ru/

Oversat fra engelsk af Niels Ivar Larsen. 